\title{
Predominant Role of Bacterial Pneumonia as a Cause of Death in Pandemic Influenza: Implications for Pandemic Influenza Preparedness
}

\author{
David M. Morens, \\ Jeffery K. Taubenberger, \\ Anthony S. Fauci \\ National Institute of Allergy and Infectious Diseases, National Institutes of Health, Bethesda, \\ Maryland
}

\begin{abstract}
Background-Despite the availability of published data on 4 pandemics that have occurred over the past 120 years, there is little modern information on the causes of death associated with influenza pandemics.
\end{abstract}

Methods-We examined relevant information from the most recent influenza pandemic that occurred during the era prior to the use of antibiotics, the 1918-1919 "Spanish flu" pandemic. We examined lung tissue sections obtained during 58 autopsies and reviewed pathologic and bacteriologic data from 109 published autopsy series that described 8398 individual autopsy investigations.

Results-The postmortem samples we examined from people who died of influenza during 1918-1919 uniformly exhibited severe changes indicative of bacterial pneumonia. Bacteriologic and histopathologic results from published autopsy series clearly and consistently implicated secondary bacterial pneumonia caused by common upper respiratory-tract bacteria in most influenza fatalities.

Conclusions-The majority of deaths in the 1918-1919 influenza pandemic likely resulted directly from secondary bacterial pneumonia caused by common upper respiratory-tract bacteria. Less substantial data from the subsequent 1957 and 1968 pandemics are consistent with these findings. If severe pandemic influenza is largely a problem of viral-bacterial copathogenesis, pandemic planning needs to go beyond addressing the viral cause alone (e.g., influenza vaccines and antiviral drugs). Prevention, diagnosis, prophylaxis, and treatment of secondary bacterial pneumonia, as well as stockpiling of antibiotics and bacterial vaccines, should also be high priorities for pandemic planning.

Reprints or correspondence: David M. Morens, MD, Bldg. 31, Room 7A-10, 31 Center Dr., MSC 2520, National Institute of Allergy and Inectious Diseases, National Institutes of Health, Bethesda, MD 20892-2520 (dmorens@ niaid.nih.gov).

Financial support: Intramural Research Program of the National Institutes of Health; National Institute of Allergy and Infectious Diseases.

Potential conflicts of interest: none reported.

Presented in part: 2006 Annual Meeting of the American Epidemiological Society, Berkeley, California, 30 March, 2006 ; and 2007 Annual Meeting of the American Epidemiological Society, Boston, Massachusetts, 26 March 2007. 
"If grippe condemns, the secondary infections execute" [1, p. 448].

_Louis Cruveilhier, 1919

Influenza pandemic preparedness strategies in the United States [2] assume 3 levels of potential severity corresponding to the 20th century pandemics of H1N1 "Spanish flu" (1918-1919), H2N2 “Asian flu” (1957-1958), and H3N2 "Hong Kong flu” (1968-1969), which were responsible for an estimated 675,000 [3], 86,000 [4], and 56,300 [5] excess deaths in the United States, respectively. Extrapolation from 1918-1919 pandemic data to the current population and age profile has led United States government officials to plan for more than 1.9 million excess deaths during a severe pandemic [2].

An important question related to pandemic preparedness remains unanswered: what killed people during the 1918-1919 pandemic and subsequent influenza pandemics? In the present study, we have examined recut tissue specimens obtained during autopsy from 58 influenza victims in 1918-1919, and have reviewed epidemiologic, pathologic, and microbiologic data from published reports for 8398 postmortem examinations bearing on this question. We have also reviewed relevant information, accumulated over 9 decades, related to the circulation of descendants of the 1918 virus. With the recent reconstruction of the 1918 pandemic influenza virus, investigators have begun to examine why it was so highly fatal [6, 7]. Based on contemporary and modern evidence, we conclude here that influenza A virus infection in conjunction with bacterial infection led to most of the deaths during the 1918-1919 pandemic.

\section{METHODS}

\section{Examination of tissue specimens from 1918-1919 influenza fatalities}

We reviewed hematoxylin and eosin-stained slides recut from blocks of lung tissue obtained during autopsy from 58 influenza fatalities in 1918-1919. These materials, sent during the pandemic from various United States military bases to the National Tissue Repository of the Armed Forces Institute of Pathology [8-10], represent all known influenza cases from this collection for which lung tissue is available.

\section{Pathology and bacteriology research records from the 1918-1919 influenza pandemic}

We reviewed the late 19th- and early 20th-century literature on gross and microscopic influenza pathology and bacteriology, including evidence from 1918-1919 autopsy series with postmortem cultures of lung tissue, blood samples (usually heart blood), pleural fluid, and samples from other compartments. In an effort to obtain all publications possibly reporting influenza pathology and/or bacteriology in 1918-1919, we searched major bibliographic sources [e.g., 11-17] for papers in all languages and tables of contents of major journals in English, German, and French; in addition, we searched all of the papers we identified for additional citations. From more than 2000 such publications, we carefully examined the 1539 reports that contained human pathologic and/or bacteriologic findings (the full bibliographic list available at http://www3.niaid.nih.gov/topics/Flu/1918/ bibliography.htm), 109 of which provided useful bacteriologic information derived from 173 autopsy series. These series reported 8398 individual autopsy investigations undertaken in 
15 countries, which can be characterized as follows: 96 postmortem lung tissue culture series, 42 blood culture series, and 35 pleural fluid culture series. When they were published as parts of an autopsy series, we included in our analyses antemortem cultures of blood and pleural fluid samples, which were mostly obtained during the terminal stages of illness. A priori, we stratified data by military and civilian populations (see Discussion), and by the quality of lung tissue culture results, considering to be of "higher quality" the 68 autopsy series with lung tissue culture results that reported, for all autopsies, both the presence and absence of negative culture results and the bacterial components of mixed culture results.

\section{RESULTS}

\section{Background epidemiologic data on influenza mortality rates in 1918-1919}

Although death certificates listing cardiac and other chronic causes of death increased in number during the time frame of the 1918-1919 pandemic [18], for all age groups death was predominantly associated with pneumonia and related pulmonary complications [13, 14, 18-20]. The pandemic caused a "W-shaped" age-specific mortality curve, which exhibited peaks in infancy, between about 20-40 years of age, and in elderly individuals $[3,21]$. In all age groups younger than $\sim 65$ years, the influenza mortality rate was elevated beyond what would have been expected on the basis of data from the previous pandemic of "Russian influenza" (1889-1893) [3, 22, 23]. The increased fatality rate in the 3 high-risk age groups was predominantly due to the increased frequency of bronchopneumonia, not to increased incidence of influenza or an increased bronchopneumonia case-fatality rate [19]. Because few autopsy reports and, to our knowledge, no autopsy series addressed conditions other than predominantly pulmonary complications, nonpulmonary causes of death are not considered here.

\section{Histologic examination of lung tissue from 1918 victims}

The examination of recut lung tissue sections from 1918-1919 influenza case material revealed, in virtually all cases, compelling histologic evidence of severe acute bacterial pneumonia, either as the predominant pathology or in conjunction with underlying pathologic features now believed to be associated with influenza virus infection [10, 24] (figure 1). The latter include necrosis and desquamation of the respiratory epithelium of the tracheobronchial and bronchiolar tree, dilation of alveolarducts, hyaline membranes, and evidence of bronchial and/or bronchiolar epithelial repair [25, 26]. The majority of the cases examined demonstrated asynchronous histopathological changes, in which the various stages of development of the infectious process, from early bronchiolar changes to severe bacterial parenchymal destruction, were noted in focal areas. The histologic spectrum observed in the cases corresponded to the characteristic pathology of bacterial pneumonia, including bronchopneumonia[10,24-33]: lobar consolidation with pulmonary infiltration by neutrophils in pneumococcal pneumonia; a bronchopneumonic pattern, edema, and pleural effusions in streptococcal and sometimes in pneumococcal pneumonia; and in staphylococcal pneumonia, multiple small abscesses with a marked neutrophilic infiltration in airways and alveoli [27]. Bacteria were commonly observed in the sections, often in massive numbers. 
Published pathologic and/or bacteriologic findings from the 1918-1919 influenza pandemic

Although the cause of influenza was disputed in 1918, there was almost universal agreement among experts [e.g., 20, 27-33] that deaths were virtually never caused by the unidentified etiologic agent itself, but resulted directly from severe secondary pneumonia caused by well-known bacterial "pneumopathogens" that colonized the upper respiratory tract (predominantly pneumococci, streptococci, and staphylococci). Without this secondary bacterial pneumonia, experts generally believed that most patients would have recovered [20]. In type, pattern, and case-fatality rate, influenza-associated bacterial pneumonia was typical of pneumonia that was endemic during periods when influenza was not prevalent [25, $28,33,34]$. As described above, in cases for which a single lung pathogen was recovered from culture, the anatomical-pathological type of the pneumonia usually corresponded to what was expected. Bacteria were commonly observed in cases of pneumonia caused by each of these pathogens. Such findings reflect the characteristic pathology of bacterial pneumonia $[10,25,27]$

Surprising aspects of 1918-1919 influenza-associated pneumonia fatalities included the following: (1) the high incidence of secondary pneumonia associated with standard bacterial pneumopathogens; (2) the frequency of pneumonia caused by both mixed pneumopathogens (particularly pneumococci and streptococci) and by other mixed upper respiratory-tract bacteria; (3) the aggressiveness of bacterial invasion of the lung, often resulting in "phenomenal" [30] numbers of bacteria and polymorphonuclear neutrophils, as well as extensive necrosis, vasculitis, and hemorrhage [20,32,33]; and (4) the predominance of bronchopneumonia and lobular pneumonia, as opposed to lobar pneumonia, consistent with diffuse predisposing bronchiolar damage [27-33].

\section{Contemporary views of the natural history of severe influenza during the 1918-1919 influenza pandemic}

By examining influenza autopsy materials from a range of patients in different stages of disease, pathologists in 1918-1919 identified the primary lesion in early severe influenzaassociated pneumonia as desquamative tracheobronchitis and bronchiolitis extending diffusely over all or much of the pulmonary tree to the alveolar ducts and alveoli, associated with sloughing of bronchiolar epithelial cells to the basal layer, hyaline membrane formation in alveolar ducts and alveoli, and ductal dilation [20, 24, 27, 29-33].

Primary "panbronchitis" [35] was thought to reflect rapidly spreading epithelial cytolytic infection of the entire bronchial tree [32, 35, 36]; this was thought to have led to the secondary spread of enormous numbers of bacteria along the denuded bronchial epithelium to every part of the bronchial tree, following which focal bronchiolar infections broke through into the lung parenchyma. Secondary bacterial invasion and zones of vasculitis, capillary thrombosis, and necrosis surrounding areas of bronchiolar damage were seen in severe cases. As was true for the 58 autopsy cases we reviewed (see above), published autopsies for victims of the 1918-1919 pandemic generally showed histopathological asynchrony [20]. Repair, represented by early epithelial regeneration, capillary repair, and occasionally by fibrosis, was commonly seen in tissues sections from even the most 
fulminant fatal cases $[20,27,32]$. Among the $₫ 60 \%$ of individuals who survived such severe pneumonia, severe chronic pulmonary damage was apparently uncommon [37, 38].

\section{Bacteriologic studies in autopsy series during the 1918-1919 influenza pandemic}

Negative lung culture results were uncommon in the 96 identified military and civilian autopsy series, which examined 5266 subjects (4.2\% of results overall) (table 1; full bibliographic list available at http://www3.niaid.nih.gov/topics/Flu/1918/bibliography.htm). In the 68 higher-quality autopsy series, in which the possibility of unreported negative cultures could be excluded, $92.7 \%$ of autopsy lung cultures were positive for $\geq 1$ bacterium (table 1). Of these 96 series, 82 reported pneumopathogens in $250 \%$ of lungs examined, either alone or in mixed culture results that included other bacteria (table 1). Outbreaks of meningococcal pneumonia complicating influenza also were documented [39]. Despite higher military case-fatality rates, the differences in the frequency with which specific bacteria were isolated from lung tissue cultures (table 1) and from culture of blood and pleural or empyema fluids (data not shown) were minimal. Many of the series were methodologically rigorous: in one study of approximately 9000 subjects who were followed from clinical presentation with influenza to resolution or autopsy [40], researchers obtained, with sterile technique, cultures of either pneumococci or streptococci from 164 of 167 lung tissue samples. There were 89 pure cultures of pneumococci; 19 cultures from which only streptococci were recovered; 34 that yielded mixtures of pneumococci and/or streptococci; 22 that yielded a mixture of pneumococci, streptococci, and other organisms (prominently pneumococci and nonhemolytic streptococci); and 3 that yielded nonhemolytic streptococci alone. There were no negative lung culture results.

In the 14 of 96 autopsy series that did not report the predominance of lung pneumopathogens [29, 36, 41-53], pneumopathogens accounted collectively for $37.4 \%$ of pneumonia deaths. The rest of the deaths were associated collectively with either culture of nonpneumopathogenic "other bacteria," such as nonhemolytic and viridans streptococci, "green-producing streptococci" [54], probably largely corresponding to $a$-hemolytic streptococci, uncharacterized diplostreptococci, Micrococcus (Moraxella) catarrhalis, Bacillus (Escherichia) coli, Klebsiella species, and complex mixed bacteria (36.1\% of cultures). Cultures also yielded Bacillus influenzae (18.8\%) and no bacterial growth $(7.7 \%)$. These findings reflect rates of bacterial isolation similar to those of the series that reported the predominance of pneumopathogens (above and table 1), but with higher isolation rates for "other bacteria" offsetting the lower isolation rates for pneumococci, streptococci and staphylococci. It is noteworthy that pneumococcal typing antisera were unavailable in 11 of these 14 studies, and that many of the cultured "other" bacteria were reported as "gram-positive diplococci," "streptococci," or "diplostreptococci" (data not shown), consistent with the possibility that in this early era of bacterial typing, some of the unidentified organisms in the culture may have been pneumopathogens.

The predominant coinfecting microorganism in lung tissue cultures containing $\geq 1$ pneumopathogen was Bacillus influenzae (largely corresponding to the modern Hemophilus influenzae), an upper respiratory-tract organism not commonly found in pure culture of samples from any anatomical compartment $[20,36,55]$. Bacillus influenzae 
tended to appear early in symptomatic influenza in association with diffuse bronchitis and/or bronchiolitis, sometimes infiltrating the bronchiolar submucosa [35]; it caused seroconversion [56] and was then typically replaced by other secondary organisms.

Cultures of blood samples in 30 military and 12 civilian series, which examined a total of 1887 subjects (table 2 ), had positive results in $70.3 \%$ of cases and typically contained either pneumococci or streptococci in pure culture. Cultures of pleural or empyema fluid, reported in 23 military and 12 civilian series examining a total of 1245 subjects (table 2), revealed either streptococci or pneumococci as the most commonly recovered organism in all but 7 series: in 4 series mixed pneumopathogens predominated, and in 3 series Staphylococcus aureus predominated. Most subjects with positive culture results in the blood and pleural or empyema fluid series also had $\geq 1$ pneumopathogen cultured in samples from the lungs (data not shown).

Of 2007 pneumococcal isolates, 874 (43.5\%) were serotyped by agglutination. Type I was isolated from 124 (14.2\%) of 874 subjects; type II from 163 (18.6\%); type IIa from 26 (3.0\%); type III from 184 (21.1\%); and type IV, a category containing diverse and, at the time, untypeable organisms, from 377 (43.1\%).

\section{Pathologic and bacteriologic information obtained from later pandemic and seasonal influenza cases}

The viruses that caused the 1957 and 1968 pandemics were descendants of the 1918 virus in which 3 (the 1957 virus) or 2 (the 1968 virus) new avian gene segments had been acquired by reassortment [21]. Although lower pathogenicity resulted in far fewer deaths, hence fewer autopsies, most 1957-1958 deaths were attributable to secondary bacterial pneumonia, as had been the case in 1918. Staphylococcus aureus, a relatively minor cause of the 1918 fatalities, was predominant in the culture results from 1957-1958 [21, 57-61], and negative lung tissue cultures were more common, possibly as a result of the widespread administration of antibiotics $[57,58,61]$. The few relevant data from the 19681969 pandemic (see below) are consistent with information from the earlier 20th-century pandemics.

Human tracheobronchial biopsy studies performed since the 1957-1958 epidemic characterized the natural history of influenza virus infection as featuring rapid (within 24 h) development of bronchial epithelial necrosis, preservation of the basal layer, limited inflammatory response, and evidence of prompt repair [62], consistent with the observations of pathologists in 1918-1919.

\section{DISCUSSION}

In the most recent influenza pandemic that did not involve the use of antibiotics to suppress bacteria (the 1918-1919 pandemic), histological and bacteriologic evidence suggests that the vast majority of influenza deaths resulted from secondary bacterial pneumonia. Compelling evidence for this conclusion includes the examination of 58 recut and restained autopsy specimens that showed changes fully consistent with classical descriptions of extensive 
bacterial pneumonia [25], culture results from numerous international autopsy series, and consistent epidemiologic and clinical findings (table 3).

Between 1890 and 1950, most observers believed fatal influenza to be a polymicrobial infection in which an inciting agent of low pathogenicity (either a bacterium such as Bacillus influenzae or a "filter passing agent"-most of which have now been identified as viruses) acted synergistically with known pneumopathogenic bacteria [13, 14, 20, 33, 64-66]. This view was dramatically supported in 1917-1918 by the measles epidemics in US Army training camps, in which most deaths resulted from streptococcal pneumonia or, less commonly, pneumococcal pneumonia [20,30,32]. The pneumonia deaths during the influenza pandemic in 1918 proved so highly similar, pathologically, to the then-recent pneumonia deaths from the measles epidemics that noted experts considered them to be the result of one newly emerging disease: epidemic bacterial pneumonia precipitated by prevalent respiratory tract agents $[20,33,63]$.

The question of whether the pathogenesis of severe influenza-associated pneumonia was primarily viral (i.e., assumed to be an unknown etiologic agent in 1918) or a combination of viral and bacterial agents was carefully considered by pathologists in 1918-1919, without definitive resolution [26, 33]. The issue was addressed anew in the early 1930s when Shope published a series of experimental studies that involved the just-discovered swine influenza A virus: severe disease in an animal model resulted only when the virus and Hemophilus influenzae suis were administered together [67]. In 1935, Brightman studied combined human influenza and streptococcal infection in a ferret intranasal inoculation model. Even though neither agent was pathogenic when administered alone, they were highly fatal in combination [68]. In rhesus monkeys, human influenza viruses given intranasally were not pathogenic, but could be made so by nasopharyngeal instillation of otherwise nonpathogenic bacteria [69]. During the 1940s, additional studies in ferrets, mice, and rats established that the influenza virus in combination with any of several pneumopathic bacteria acted synergistically to produce either a higher incidence of disease, a higher death rate, or a shortened time to death [70-73]; these effects could be mitigated or eliminated if antibiotics were given shortly after establishment of combined infection [73]. More recent data suggest that influenza vaccination may prevent bacterial disease [74].

As reviewed recently by McCullers [75], a body of experimental research during the last 3 decades has identified possible mechanisms by which coinfection with the influenza virus and bacteria might affect pathogenicity. These include viral neuraminidase (NA)induced exposure of bacterial adherence receptors; bacterial NA-induced upregulation of influenza infection; interleukin 10-induced susceptibility to pneumococci and possibly staphylococci [76]; interferon type 1 effects [77]; viral PB1-F2 effects, the proaptotic and mitochondriopathic effects of which are correlated with enhanced bacterial infection [78]; and virus-induced desensitization to bacterial Toll-like receptor ligands [79].

We believe that the weight of 90 years of evidence (table 3), including the exceptional but largely forgotten work of an earlier generation of pathologists, indicates that the vast majority of pulmonary deaths from pandemic influenza viruses have resulted from poorly understood interactions between the infecting virus and secondary infections due to 
bacteria that colonize the upper respiratory tract. The data are consistent with a natural history in which the virus, highly cytopathic to bronchial and bronchiolar epithelial cells, extends rapidly and diffusely down the respiratory tree, damages the epithelium sufficiently to break down the mucociliary barrier to bacterial spread, and if able to gain access to the distal respiratory tree-perhaps on the basis of receptor affinity [80]creates both a direct pathway for secondary bacterial spread and an environment (cell necrosis and proteinaceous edema fluid) favorable to bacterial growth. It remains unresolved whether cocolonizing, nonpneumopathic upper respiratory-tract organisms such as Bacillus (Hemophilus) influenzae play an ancillary role, or are merely innocent bystanders. It is uncertain why Hemophilus influenzae was much less prominent in 1957-1958 and thereafter, but this phenomenon may relate to antibiotic use and conceivably, in recent years, to Hemophilus influenzae $b$ vaccination of children.

The extraordinary severity of the 1918 pandemic remains unexplained. That the causes of death included so many different bacteria, alone or in complex combinations, argues against specific virulent bacterial clones. The pathologic and bacteriologic data appear consistent with copathogenic properties of the virus itself, perhaps related to viral growth, facility of cell-to-cell spread, cell tropism, or interference with or induction of immune responses. Certain observers believed that cotransmission of the influenza agent and of pneumopathogenic bacteria was responsible for many severe and fatal cases, especially during the October-November 1918 peak of mortality and case-fatality rates [81]. We speculate that any influenza virus with an enhanced capacity to spread to and damage bronchial and/or bronchiolar epithelial cells, even in the presence of an intact rapid reparative response, could precipitate the appearance of severe and potentially fatal bacterial pneumonia due to prevalent upper respiratory-tract bacteria.

In the modern era, the widespread use of antibiotics and the establishment of life-prolonging intensive care unit treatment make it more difficult than it was in 1918 to document the importance of bacterial lung infection for influenza-related mortality. Influenza-associated pneumonia patterns may now be influenced by the administration of pneumococcus, Hemophilus influenzae $b$, and meningococcus vaccine, and cases have tended to occur in elderly individuals, who rarely undergo autopsy. The 1968 influenza pandemic was mild, and autopsy studies were uncommon [21]. Fatal cases of influenza-associated viral pneumonia that are considered to be "primary" (i.e., with little or no bacterial growth) continue to be identified $[82,83]$; however, their incidence appears to be low, even in pandemic peaks. The issue of the pathogenesis of fatal influenza-associated pneumonia remains important; the fact that even severe, virus-induced tissue damage is normally followed by rapid and extensive repair $[20,26]$ suggests that early and aggressive treatment, including antibiotics and intensive care, could save most patients $[84,85]$ and also underscores the importance of prevention and prophylaxis.

The 1918 pandemic and subsequent pandemics differed with respect to the spectrum and extent of secondary bacterial pneumonia (e.g., the switch in prevalence during the antibiotic era to predominantly staphylococcal secondary pneumonia, as opposed to streptococcal, pneumococcal, and mixed secondary pneumonia; and the greatly decreased involvement of Bacillus [Hemophilus] influenzae), suggesting that additional factors affect the level of 
influenza morbidity and mortality. These might include the use of antibiotics and antiviral agents, the rate of influenza vaccination and bacterial vaccination, and demographic and social factors. The aging population in the United States, the increasing number of persons living in nursing home facilities, and the number of persons who are immunosuppressed or affected by cardiac disease, renal disease, and/or diabetes mellitus all represent potential factors that might change the profile of morbidity and mortality during a future pandemic. For example, elderly persons in nursing homes are at risk for pneumonia caused by enteric organisms and sometimes by drug-resistant nosocomial organisms. The spread of bacteria such as methicillin-resistant Staphylococcus aureus and highly pathogenic clones of Streptococcus pyogenes pose more general risks [86].

The viral etiology of and timing of the next influenza pandemic cannot be predicted [87]. If, as some fear, a future pandemic is caused by a derivative of the current highly pathogenic avian $\mathrm{H} 5 \mathrm{~N} 1$ virus, lessons from previous pandemics may not be strictly applicable.

Although histopathologic information concerning current human H5N1 infections is sparse [10], its pathogenic mechanisms may be atypical because the virus is poorly adapted to humans [88] and because, in certain experimental animal models [e.g., 89], some strains have induced severe pathology that differs from the findings associated with circulating human influenza viruses (which, in these models, cause disease resembling self-limited seasonal influenza in humans [90]). However, if an H5N1 virus were to fully adapt to humans, the clinicopathologic spectrum of associated disease could become more like that of previous pandemics.

If the next pandemic is caused by a human-adapted virus similar to those recognized since 1918, we believe the infection is likely to behave as it has in past pandemics, precipitating severe disease associated with prevalent colonizing bacteria. Recent reviews have discussed the importance of new and improved influenza antiviral drugs and influenza vaccines in controlling a pandemic [84, 91, 92]. The present work leads us to conclude that in addition to these critical efforts, prevention, diagnosis, prophylaxis, and treatment of bacterial pneumonia, as well as the stockpiling of antibiotics and bacterial vaccines [84, $85,93]$, should be among the highest priorities in pandemic planning. We are encouraged that such considerations are already being discussed and implemented by the agencies and individuals responsible for such plans [94, 95].

\section{Acknowledgments}

We thank Betty Murgolo and the staff of the National Institutes of Health (NIH) Library, for extensive research efforts in locating publications, and the staff of the History of Medicine Division, National Library of Medicine, $\mathrm{NIH}$, for additional library research support. We also thank Cristina Cassetti, PhD, and Andrea Scollard, DDS, $\mathrm{PhD}$ for translation of Italian language and Portuguese language papers, respectively; Hillery A. Harvey, $\mathrm{PhD}$, for scientific assistance; and Gregory K. Folkers, MS, MPH, for helpful discussion and editorial assistance. John J. McGowan, PhD, and the staff of the National Institute of Allergy and Infectious Diseases (NIAID) Pandemic Influenza Digital Archives project provided substantial assistance in organizing and indexing historical manuscripts.

\section{References}

1. Cruveilhier L. Action du sérum antipneumococcique au cours de la pneumonie et dans les complications de la grippe. Annales de l'Institut Pasteur. 1919; 33: 448-61. 
2. United States Department of Health and Human Services (HHS). HHS pandemic influenza plan. Washington, DC: US Government Printing Office; 2005. Available at: http://www.hhs.gov/ pandemicflu/plan/pdf/HHSPandemicInfluenzaPlan.pdf [16 June 2008]

3. Morens DM, Fauci AS. The 1918 influenza pandemic: insights for the 21 st century. J Infect Dis. 2007; 195: 1018-28. [PubMed: 17330793]

4. Dauer CC, Serfling RE. Mortality from influenza 1957-1958 and 1959-1960. Am Rev Respir Dis. 1961; 83 (Suppl) 15-28.

5. Alling DW, Blackwelder WC, Stuart-Harris CH. A study of excess mortality during influenza epidemics in the United States, 1968-1976. Am J Epidemiol. 1981; 113: 30-43. [PubMed: 7457477]

6. Tumpey TM, Basler CF, Aguilar PV, et al. Characterization of the reconstructed 1918 Spanish influenza pandemic virus. Science. 2005; 310: 77-80. [PubMed: 16210530]

7. Palese P, Tumpey TM, Garcia-Sastre A. What can we learn from reconstructing the extinct 1918 pandemic influenza virus? Immunity. 2006; 24: 121-4. [PubMed: 16473822]

8. Taubenberger JK, Reid AH, Krafft AE, Bijwaard KE, Fanning TG. Initial genetic characterization of the 1918 "Spanish" influenza virus. Science. 1997; 275: 1793-6. [PubMed: 9065404]

9. Reid AH, Fanning TG, Hultin JV, Taubenberger JK. Origin and evolution of the 1918 "Spanish" influenza virus hemagglutinin gene. Proc Natl Acad Sci U S A. 1999; 96: 1651-6. [PubMed: 9990079]

10. Taubenberger JK, Morens DM. The pathology of influenza virus infections. Annu Rev Pathol Mech Dis. 2008; 3: 499-522.

11. Billings, JS, Fletcher, R, Garrison, FH, editors. Index Medicus. Vol. 18. Washington, DC: Government Printing Office; 1903-1920.

12. Library of the Surgeon General's Office, United States Army. Index-catalogue of the Library of the Surgeon-General's Office, United States Army. Authors and Subjects. Vol. 10. Washington, DC: US Government Printing Office; 1918-1932.

13. Vaughan, WT. Influenza: an epidemiological study. Monograph series no. 1. Baltimore, Maryland: American Journal of Hygiene; 1921.

14. Jordan, EO. Epidemic influenza: a survey. Chicago, Illinois: American Medical Association; 1927.

15. Thomson, D, Thomson, R. With special reference to the complications and sequellæ, bacteriology of influenzal pneumonia, pathology, epidemiological data, prevention and treatment. London: Baillière, Tindall \& Cox; 1934. Annals of the Pickett-Thomson Research Laboratory Volume X. Influenza (Part II).

16. Phillips, H, Killingray, D, editors. The Spanish Influenza Pandemic of 1918-19. New Perspectives. London: Routledge; 2003.

17. Byerly, CR. Fever of War: the influenza epidemic in the U. S. Army during World War I. New York: New York University Press; 2005.

18. Frankel LK, Dublin LI. Influenza mortality among wage earners and their families. A preliminary statement of results. Am J Public Health. 1919; 9: 731-42.

19. Collins SD. Age and sex incidence of influenza and pneumonia morbidity and mortality in the epidemic of 1928-29 with comparative data for the epidemic of 1918-19. Public Health Rep. 1931; 46: 1909-37. [PubMed: 19315308]

20. Opie, EL, Blake, FG, Rivers, TM. The pathology and bacteriology of pneumonia following influenza. In: Opie, EL, Blake, FG, Small, JC, Rivers, TM, editors. Epidemic respiratory disease. The pneumonias and other infections of the respiratory tract accompanying influenza and measles. Vol. Chapter IV. St Louis: CV Mosby; 1921. 107-281.

21. Taubenberger JK, Morens DM. 1918 influenza: the mother of all pandemics. Emerg Infect Dis. 2006; 12: 15-22. [PubMed: 16494711]

22. Legislative Assembly, New South Wales. Report of the Director-General of Public Health, New South Wales, for the Year 1919, including a report on the influenza epidemic, 1919. Sydney: William Applegate Gullick; 1920.

23. Reid AH, Taubenberger JK. The 1918 flu and other influenza pandemics: "over there" and back again. Lab Invest. 1999; 79: 95-101. [PubMed: 10068198] 
24. Hers JFP, Masurel N, Mulder J. Bacteriology and histopathology of the respiratory tract and lungs in fatal Asian influenza. Lancet. 1958; 2: 1141-3. [PubMed: 13612141]

25. Mulder, J, Hers, JFP. Influenza. Groningen: Wolters-Noordhoff; 1972.

26. Hers, JFP. The histopathology of the respiratory tract in human influenza. Leiden: HE Stenfert; 1955.

27. Goodpasture EW. The significance of certain pulmonary lesions in relation to the etiology of influenza. Am J Med Sci. 1919; 158: 863-70.

28. Klotz, O. Members of the Faculty of the School of Medicine, University of Pittsburgh. Studies on epidemic influenza comprising clinical and laboratory investigations by Members of the Faculty of the School of Medicine, University of Pittsburgh. Pittsburgh: University of Pittsburgh; 1919. The pathology of epidemic influenza; 207-294.

29. Lucke B, Wight T, Kime E. Pathologic anatomy and bacteriology of influenza: epidemic of autumn, 1918. Arch Intern Med. 1919; 24: 154-237.

30. MacCallum WG. Pathology of epidemic pneumonia in camps and cantonments in 1918. Med Rec. 1919; 95: 776-84.

31. Tobias JW. Anatomía Patológica de la grippe pandémica. Rev Med Univ Buenos Aires. 1920; 17: 109-99.

32. Winternitz, MC, Wason, IM, McNamara, FP. The pathology of influenza. New Haven: Yale University Press; 1920.

33. MacCallum WG. Pathological anatomy of pneumonia associated with influenza; 23 plates. Johns Hopkins Hosp Rep. 1921; 20: 149-249.

34. Kelly FB. Observations on 6,500 cases of lobar pneumonia at the Cook County Hospital, Chicago. J Infect Dis. 1926; 38: 24-36.

35. Reckford FFD. Acute alveolar and interstitial emphysema in influenza bronchopneumonia. Pennsylvania Med J. 1920; 23: 379-87.

36. Roos C. Notes on the bacteriology, and on the selective action of B. influenzae Pfeiffer. J Immunol. 1919; 4: 189-201.

37. Wynn WH. Chronic influenzal fibrosis of the lungs. Lancet. 1927; 2: 964-7.

38. Nuzum JW, Pilot I, Stangl FH, Bonar BE. Pandemic influenza and pneumonia in a large civil hospital. J Am Med. 1918; 71: 1562-5.

39. Holm ML, Davison WC. Meningococcus pneumonia. I. The occurrence of post-influenzal pneumonia in which the diplococcus intracellularis meningitidis was isolated. From observations at Camp Coetquidon, A. E. F., France. Bull Johns Hopkins Hosp. 1919; 30: 324-9.

40. Hirsch EF, McKinney M. An epidemic of pneumococcus bronchopneumonia. J Infect Dis. 1919; 24: 594-617.

41. Little TR. Discussion on influenza. Proc R Soc Med (Great Britain). 1918; 12: 36-41.

42. Rucker JB, Wenner JJ. Friedländer bacillus, the causative factor in bronchopneumonia following influenza. Proc Pathol Soc Philadelphia. 1918; 21: 41-2.

43. Rucker JB, Wenner JJ. Friedlander bacillus the causative factor in bronchopneumonia following influenza. N Y Med J. 1918; 108: 1066-9.

44. Abrahams A, Hallows N, French H. A further investigation into influenzo-pneumococcal and influenzo-streptococcal septicæmia: epidemic influenzal "pneumonia" of highly fatal type and its relation to "purulent bronchitis". Lancet. 1919; 1: 1-11.

45. Findlay GM. Notes on the bacteriology of influenza epidemic in Lower Egypt. Lancet. 1919; 1: 1113-14.

46. Fiore G. Contributo allo studio batteriologico dell'epidemia di influenza 1918. Riv Clin Pediatr (Firenze). 1919; 17: 281-303.

47. Gibson, HG, Bowman, FB. MRC (Medical Research Council). Special Report Series, No. 36. Studies of influenza in hospitals of the British Armies in France, 1918: part I. Abbeville Research Team. Vol. 2. London: His Majesty's Stationery Office; 1919. The bacteriological flora of the respiratory tract in cases of influenza; $37-46$.

48. Medalia LS. Influenza epidemic at Camp MacArthur: etiology, bacteriology, pathology, and specific therapy. Boston Med Surg J. 1919; 180: 323-30. 
49. Moses A. Bacteriologia da grippe. Bras Med. 1919; 33: 37-9.

50. Spooner LH, Scott JM, Heath EH. A bacteriologic study of the influenza epidemic at Camp Devens, Mass. J Am Med Assoc. 1919; 72: 155-9.

51. Baker SL. Report on bacteriological work on influenza at the Royal Naval Hospital, Haslar. J R Nav Med Serv. 1920; 6: 446-53.

52. Bakwin H. Gross pathology of influenzal pneumonia in France. Am J Med Sci. 1920; 159: 435-42.

53. Schärer, R. Zur pathologischen Anatomie der Grippe. Mit besonderer Berücksichtigung der mikroskopischen Lungenbefunde [inaugural dissertation]. Bern: Paul Haupt; 1920.

54. Tunnicliff R. Observations on green producing cocci of influenza. J Infect Dis. 1920; 26: 405-17.

55. Harkavy J, Selby JH. Influenza pneumonia from a clinical and X-ray study. Am J Roentgenol. 1920; 7: 109-16. 148-65.

56. Wollstein M. Pfeiffer's bacillus and influenza: a serological study. J Exp Med. 1919; 30: 555-68. [PubMed: 19868377]

57. Mark DD. The pathology of 1957 (Asian) influenza. Am Rev Tuberc Pulmon Dis. 1959; 79: 440-9.

58. Robertson L, Caley JP, Moore J. Importance of Staphylococcus aureus in pneumonia in the 1957 epidemic of influenza A. Lancet. 1958; 2: 233-6. [PubMed: 13564806]

59. Louria DB, Blumenfeld HL, Ellis JT, Kilbourne ED, Rogers DE. Studies on influenza in the pandemic of 1957-1958. II. Pulmonary complications of influenza. J Clin Invest. 1959; 38: 213 65. [PubMed: 13620784]

60. Oswald NC, Shooter RA, Curwen MP. Pneumonia complicating Asian influenza. Br Med J. 1958; 2: 1305-11. [PubMed: 13596593]

61. Oseasohn R, Adelson L, Kaji M. Clinicopathologic study of thirty-three fatal cases of Asian influenza. N Engl J Med. 1959; 260: 509-18. [PubMed: 13632920]

62. Walsh JJ, Dietlein LF, Low FN, Burch GE, Mogabgab WJ. Bronchotracheal response in human influenza, type A Asian strain, as studied by light and electron microscopic examination of bronchoscopic biopsies. Arch Intern Med. 1961; 108: 376-88. [PubMed: 13782910]

63. MacCallum WG. Pathological studies in the recent epidemics of pneumonia. Trans South Surg Assoc. 1918-1919; 31: 180-92.

64. Leichtenstern O. Mittheilungen über die Influenzaepidemie in Köln. Dtsch Med Wochenschr. 1890; 16: 212-5. 320-1, 388-9, 485-6, 509-11, 642-3, 665-6, 936-40, 957-8.

65. Maxwell ES, Ward TG, Van Metre TE. The relation of influenza virus and bacteria in the etiology of pneumonia. J Clin Invest. 1949; 28: 307-18. [PubMed: 16695680]

66. Taubenberger JK, Hultin JV, Morens DM. Discovery and characterization of the 1918 pandemic influenza virus in historical context. Antivir Ther. 2007; 12: 581-91. [PubMed: 17944266]

67. Shope RE. Swine influenza. III. Filtration experiments and etiology. J Exp Med. 1931; 54: 373-85. [PubMed: 19869924]

68. Brightman IJ. Streptococcus infection occurring in ferrets inoculated with human influenza virus. Yale J Biol Med. 1935; 8: 127-35. [PubMed: 21433668]

69. Wilson HE, Saslaw S, Doan CA, Woolpert OC, Schwab JL. Reactions of monkeys to experimental mixed influenza and Streptococcus infections. An analysis of the relative roles of humoral and cellular immunity, with the description of an intercurrent nephritic syndrome. J Exp Med. 1947; 85: 199-215. [PubMed: 19871608]

70. Glover RE. Spread of infection from the respiratory tract of the ferret. II. Association of influenza A virus and Streptococcus group C. Br J Exp Pathol. 1941; 22: 98-107.

71. Schwab JL, Blubaugh FC, Woolpert OC. The response of mice to the intranasal inoculation of mixtures of Streptococcus hemolyticus and influenza virus. J Bacteriol. 1941; 41: 59-60.

72. Francis T, Vicente de Torregrosa M. Combined infection of mice with $H$. influenzae and influenza virus by the intranasal route. J Infect Dis. 1945; 76: 70-7.

73. Harford CG, Smith MR, Wood WB. Sulfonamide chemotherapy of combined infection with influenza virus and bacteria. J Exp Med. 1946; 83: 505-18. 
74. Lee S-E, Eick A, Bloom MS, Brundage JF. Influenza immunization and subsequent diagnoses of group A Streptococcus-illnesses among US Army trainees, 2002-2006. Vaccine. 2008; 26: 3383-6. [PubMed: 18501484]

75. McCullers JA. Insights into the interaction between influenza virus and pneumococcus. Clin Microbiol Rev. 2006; 19: 571-82. [PubMed: 16847087]

76. van der Sluijs KF, Nijhuis M, Levels JHM, et al. Influenza-induced expression of indoleamine 2,3-dioxygenase enhances interleukin-10 production and bacterial outgrowth during secondary pneumococcal pneumonia. J Infect Dis. 2006; 193: 214-22. [PubMed: 16362885]

77. Navarini AA, Recher M, Lang KS, et al. Increased susceptibility to bacterial superinfection as a consequence of innate antiviral responses. Proc Natl Acad Sci U S A. 2006; 103: 15535-9. [PubMed: 17030789]

78. McAuley JL, Hornung F, Boyd KL, et al. Expression of the 1918 influenza A virus PB1-F2 enhances the pathogenesis of viral and secondary bacterial pneumonia. Cell Host Microbe. 2007; 2: 240-9. [PubMed: 18005742]

79. Didierlaurent A, Goulding J, Patel S, et al. Sustained desensitization to bacterial Toll-like receptor ligands after resolution of respiratory influenza infection. J Exp Med. 2008; 205: 323-329. [PubMed: 18227219]

80. Stevens J, Blixt O, Glaser L, et al. Glycan microarray analysis of the hemagglutinins from modern and pandemic influenza viruses reveals different receptor specificities. J Mol Biol. 2006; 355: 1143-55. [PubMed: 16343533]

81. Logan WR. A study of the pneumococcus and streptococcus groups in their relation to influenza. Edinburgh Med J. 1921; 26: 294-312.

82. Bogart DB, Liu C, Ruth WE, Kerby GR, Williams CH. Rapid diagnosis of primary influenza pneumonia. Chest. 1975; 68: 513-7. [PubMed: 1175410]

83. Guarner J, Paddock CD, Shieh W-J, et al. Histopathologic and immunohistochemical features of fatal influenza virus infection in children during the 2003-2004 season. Clin Infect Dis. 2006; 43: 132-40. [PubMed: 16779738]

84. Memoli MJ, Morens DM, Taubenberger JK. Pandemic and seasonal influenza: therapeutic challenges. Drug Discov Today. 2008; 13: 590-5. [PubMed: 18598914]

85. Brundage JF. Interactions between influenza and bacterial respiratory pathogens: implications for pandemic preparedness. Lancet Infect Dis. 2006; 6: 303-12. [PubMed: 16631551]

86. Rothberg MB, Haessler SD, Brown RB. Complications of viral influenza. Am J Med. 2008; 121: 258-64. [PubMed: 18374680]

87. Taubenberger JK, Morens DM, Fauci AS. The next influenza pandemic: can it be predicted? JAMA. 2007; 297: 2025-27. [PubMed: 17488968]

88. Writing Committee of the Second World Health Organization Consultation on Clinical Aspects of Human Infection with Avian Influenza A (H5N1) Virus: update on avian influenza A (H5N1) virus infection in humans. N Engl J Med. 2008; 358: 261-73. [PubMed: 18199865]

89. Salomon R, Franks J, Govorkova EA, et al. The polymerase complex genes contribute to the high virulence of the human H5N1 influenza virus isolate A/Vietnam/1203/04. J Exp Med. 2006; 203: 689-97. [PubMed: 16533883]

90. Reuman PD, Keely S, Schiff GM, James N. Assessment of signs of influenza illness in the ferret model. J Virol Methods. 1989; 24: 27-34. [PubMed: 2760163]

91. Palese P. Influenza: old and new threats. Nat Med. 2004; 10 (12 Suppl) S82-7. [PubMed: 15577936]

92. Subbarao K, Murphy BR, Fauci AS. Development of effective vaccines against pandemic influenza. Immunity. 2006; 24: 5-9. [PubMed: 16413916]

93. Scientific Advisory Group on Pandemic Influenza, Department of Health (United Kingdom). Review of the evidence base underpinning clinical countermeasures and risk from H5N1. 16 June 2008 Available at: http://www.dh.gov.uk/en/Publicationsandstatistics/Publications/ PublicationsPolicyAndGuidance/DH_077276

94. US Centers for Disease Control and Prevention. Strategic National Stockpile. 2008. 16 June 2008 Available at: https://aspr.hhs.gov/SNS/Pages/default.aspx 
95. World Health Organization. Pandemic preparedness. 2008. 16 June 2008 Available at: http:// www.who.int/csr/disease/influenza/pandemic/en/ 

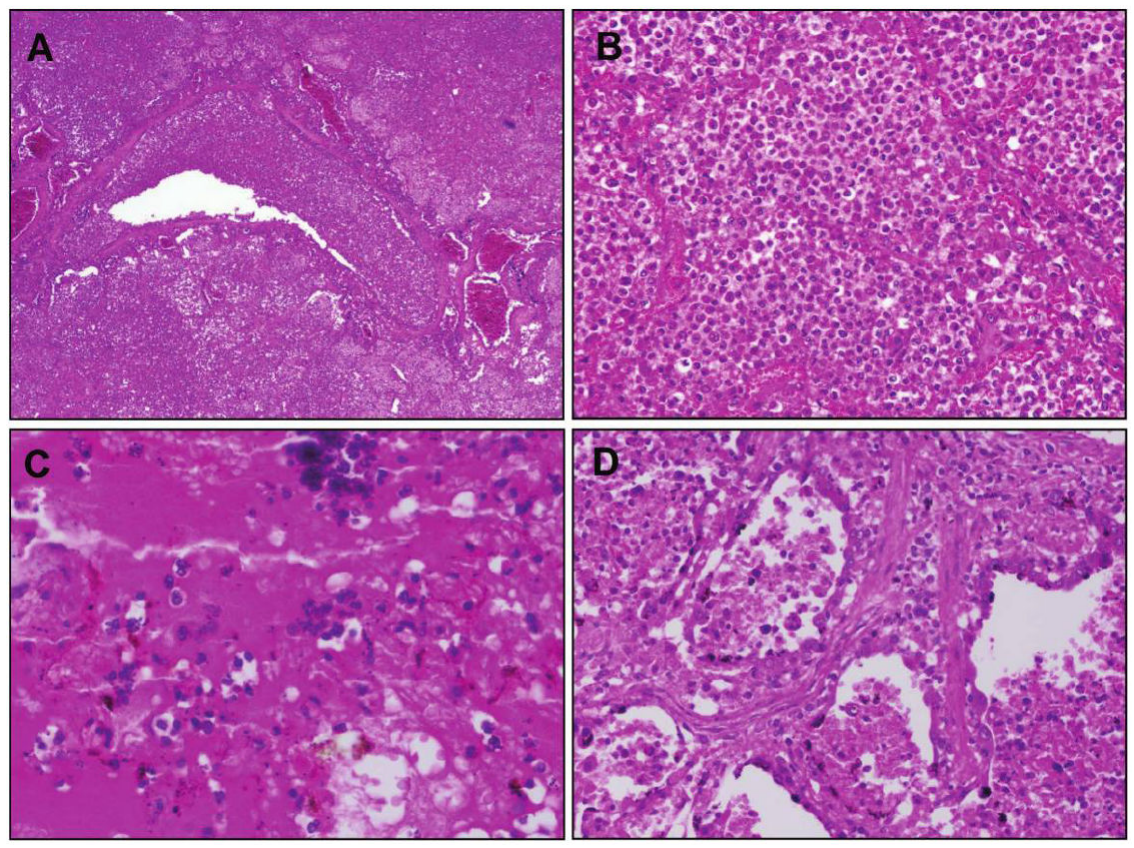

Figure 1.

Examples of hematoxylin and eosin-stained postmortem lung sections from 4 victims of the 1918-1919 influenza pandemic (see text). A, Typical picture of severe, widespread bacterial bronchopneumonia with transmural infiltration of neutrophils in a bronchiole and with neutrophils filling the airspaces of surrounding alveoli (original magnification, 40x). $B$, Massive infiltration of neutrophils in the airspaces of alveoli associated with bacterial bronchopneumonia as in A (original magnification, 200x). $C$, Bronchopneumonia with intra-alveolar edema and hemorrhage. Numerous bacteria are visible both in the edema fluid and in the cytoplasm of macrophages (original magnification, 400×). $D$, Bronchopneumonia with evidence of pulmonary repair. The alveolar epithelium is hyperplastic; interstitial fibrosis is seen between alveoli (original magnification, 200x). 


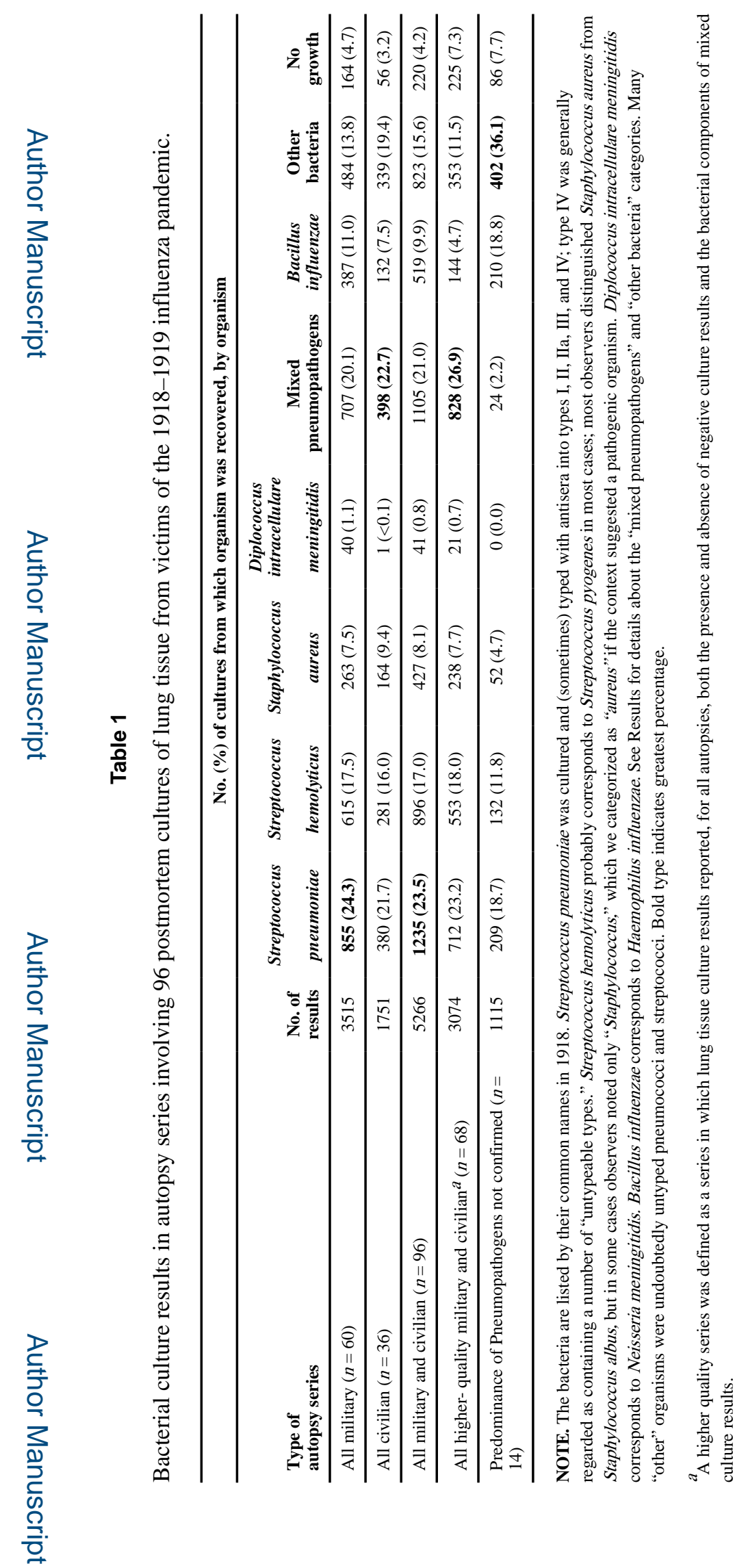

J Infect Dis. Author manuscript; available in PMC 2009 October 01. 


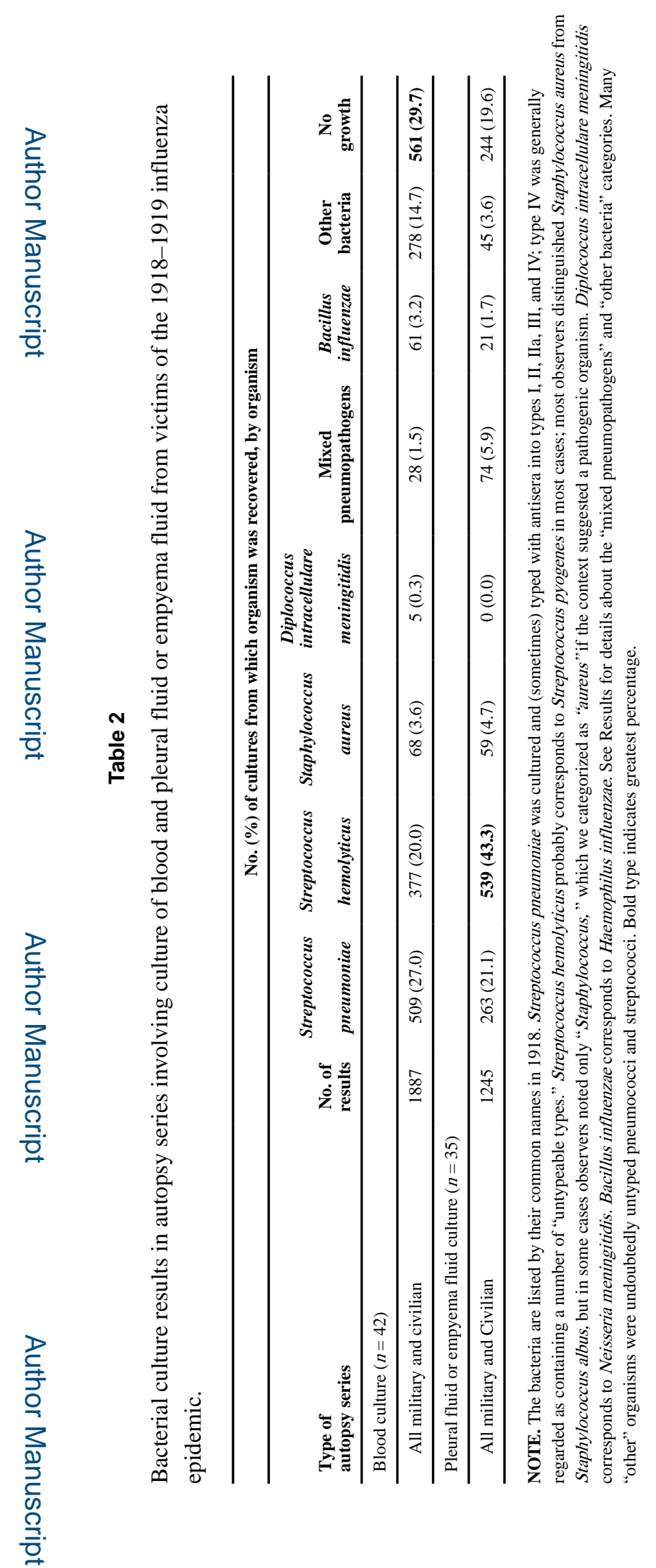

J Infect Dis. Author manuscript; available in PMC 2009 October 01. 


\section{Table 3}

Summary of evidence from the 1918-1919 influenza pandemic consistent with the conclusion that bacterial pneumonia, rather than primary viral pneumonia, was the cause of most deaths.

\begin{tabular}{|c|c|}
\hline Evidence, by type & $\begin{array}{c}\text { Relevant } \\
\text { reference(s) }\end{array}$ \\
\hline \multicolumn{2}{|l|}{ Pathologic Evidence } \\
\hline Most autopsies revealed severe bacterial pneumonia caused by common upper respiratory organisms & $\{20,27-33\}$ \\
\hline $\begin{array}{l}\text { In type, pattern, and case-fatality rate, influenza-associated bacterial pneumonia, including chronic lobar pneumonia, } \\
\text { was typical of pneumonia during periods when influenza was not prevalent; bronchopneumonia, associated with diffuse } \\
\text { "panbronchitis," predominated }\end{array}$ & {$[25,28,33,34]$} \\
\hline $\begin{array}{l}\text { At autopsy, early and/or extensive repair of what are now thought to be primary viral changes was evident; severe } \\
\text { sequelae in pneumonia survivors were minimal }\end{array}$ & {$[20,30,32]$} \\
\hline $\begin{array}{l}\text { Pathologic picture of bacterial bronchopneumonia associated with influenza in 1918-1919 was strongly similar to the } \\
\text { more highly fatal measles-bacterial bronchopneumonia epidemics of 1917-1918 }\end{array}$ & {$[20,27,63]$} \\
\hline Mixed pneumopathogen-associated pneumonia was more fatal than single-pneumopathogen pneumonia & [29] \\
\hline $\begin{array}{l}\text { Pneumonia cases exhibited uniformly diffuse and extensive tracheobronchitis and/or bronchiolitis, the severity of } \\
\text { which correlated with pneumonia severity in degree and anatomical location }\end{array}$ & [29] \\
\hline \multicolumn{2}{|l|}{ Demographic and/or epidemiologic evidence } \\
\hline Most influenza cases were typical of cases seen today: mild, uncomplicated, and associated with full recovery & {$[13-17]$} \\
\hline $\begin{array}{l}\text { Mortality at all ages was associated with bacterial pneumonia rates, not with influenza attack rates or pneumonia } \\
\text { case-fatality rates }\end{array}$ & {$[19,21]$} \\
\hline $\begin{array}{l}\text { Children 5-15 years old in 1918-1919 had the highest attack rates but the lowest mortality rates, similar to low rates } \\
\text { seen in 1889-1893 and immediately before and after the 1918-1919 pandemic-rates seemingly inconsistent with viral } \\
\text { virulence alone }\end{array}$ & {$[14,21]$} \\
\hline $\begin{array}{l}\text { Influenza-associated pneumonia incidence rates and influenza death rates were significantly higher in US military } \\
\text { camps, which experienced bacterial "colonization epidemics" }\end{array}$ & {$[63]$} \\
\hline $\begin{array}{l}\text { Average time from influenza onset to pneumonia onset in ultimately fatal cases ( } \sim 10 \text { days) may be more consistent } \\
\text { with bacterial than viral pneumonia }\end{array}$ & [29] \\
\hline \multicolumn{2}{|l|}{ Treatment response evidence } \\
\hline $\begin{array}{l}\text { The near universal observation that strict bed rest early in the course of uncomplicated influenza prevented } \\
\text { pneumonia and death is consistent with an effect of isolation from carriers of bacterial pathogens }\end{array}$ & {$[13,14]$} \\
\hline
\end{tabular}

